\title{
New geophysical data from a key region in East Antarctica: Estimates for the spatial extent of the Tonian Oceanic Arc Super Terrane (TOAST)
}

\author{
Antonia Ruppel ${ }^{\mathrm{a}, *}$, Joachim Jacobs ${ }^{\mathrm{b}, \mathrm{c}}$, Graeme Eagles ${ }^{\mathrm{d}}$, Andreas Läufer ${ }^{\mathrm{a}}$, Wilfried Jokat ${ }^{\mathrm{d}}$ \\ a Federal Institute for Geosciences and Natural Resources (BGR), Stilleweg 2, 30655 Hannover, Germany \\ b University of Bergen, Department of Earth Science, P.O. Box 7800, 5020 Bergen, Norway \\ c Norwegian Polar Institute, Fram Centre, 9296 Tromsø, Norway \\ d Alfred Wegener Institute (AWI), Helmholtz Centre for Polar and Marine Research, Am Alten Hafen 26, 27570 Bremerhaven, Germany
}

\section{A R T I C L E I N F O}

\section{Article history:}

Received 27 September 2017

Received in revised form 9 January 2018

Accepted 14 February 2018

Available online 28 March 2018

Handling Editor: T. Tsunogae

\section{Keywords:}

Airborne magnetics

Subglacial geology

Tonian Oceanic Arc Super Terrane (TOAST)

Sør Rondane

Eastern Dronning Maud Land

\begin{abstract}
A B S T R A C T
Within Antarctica, eastern Dronning Maud Land (DML) represents a key region for improving our understanding of crustal fragments that were involved in the amalgamation and breakup histories of Rodinia and Gondwana. An aerogeophysical survey was flown during the austral summers 2013/14 and 2014/15 to explore the largely icecovered region south and east of Sør Rondane. Here, we present 40,000 new line kilometer of aeromagnetic data gathered across an area of ca. 295,000 km² with a $10 \mathrm{~km}$ line spacing. Magnetic domains, major lineaments, locations, and depths of magnetic source bodies are detected from total field data, their tilt derivative, pseudogravity, and analytical signal transformations, and from Euler Deconvolution maps. These data are integrated with exposure information from the Sør Rondane, Belgica and the Yamato mountains in order to identify the eastern spatial extent of a major juvenile Early Neoproterozoic crustal province, the Tonian Oceanic Arc Super Terrane (TOAST). Magnetic data reveal a characteristic pattern with NW-SE trending elongated magnetic anomalies to the south of Sør Rondane. This area is interpreted as the eastward continuation of the distinct SE DML Province and therefore of the TOAST. Major curvilinear magnetic anomalies of several hundreds of kilometers length dissect the region south and southwest of Sør Rondane. These may represent boundaries of individual oceanic arc terrane or alternatively major Pan-African shear zones. A significant change of the magnetic anomaly pattern ca. $800 \mathrm{~km}$ inland of Sør Rondane may indicate the southern minimum extent of the TOAST. Magnetic anomalies of varying size, amplitude, and orientation suggest a complex transitional area between the Belgica and Yamato Mts., which appears to separate the TOAST from an Indo-Antarctic craton to the east. The new data suggest that the TOAST is comparable in size with the Antarctic Peninsula and therefore represents a significant piece of Neoproterozoic crustal addition. It originated at the periphery or outboard of Rodinia and is a remnant of the Mozambique Ocean.
\end{abstract}

(c) 2018 International Association for Gondwana Research. Published by Elsevier B.V. All rights reserved.

\section{Introduction}

East Antarctica amalgamated along a network of Late Neoproterozoic/Early Palaeozoic mobile belts during the formation of Gondwana (e.g. Shiraishi et al., 1994; Jacobs et al., 1998; Fitzsimons, 2000; Meert, 2003). Prior to the Neoproterozoic, these fragments were variously attached to Kalahari, India and Australia (e.g. Dalziel, 1991; Moyes et al., 1993; Boger et al., 2001; Fitzsimons, 2003; Jacobs et al., 2008). However, the geometries of these blocks and the outlines of mobile belts and suture zones between them are poorly known because of the mostly ice-covered nature of Antarctica. In Antarctica, systematic aerogeophysical surveys have proven to be very valuable for characterizing the subglacial basement, by integration with surface geology from

\footnotetext{
* Corresponding author.

E-mail address: Antonia.Ruppel@BGR.de (A. Ruppel).
}

the continent's scarce outcrops (e.g. Golynsky et al., 2007; Riedel et al., 2013; Mieth and Jokat, 2014; Mieth et al., 2014).

Dronning Maud Land (DML) is a key region for better understanding the amalgamation of various parts of East Antarctica during the reassembly of Rodina into Gondwana (Fig. 1). DML is dissected by the major ca. 650-500 Ma East African-Antarctic Orogen, which is part of the trans-Gondwana network of Late Neoproterozoic/Early Palaeozoic mobile belts (Jacobs et al., 1998, 2003; Jacobs and Thomas, 2004). Various parts of east and west Gondwana collided along the East AfricanAntarctic Orogen, forming a long (>8000 km) mobile belt that displays a variety of tectonic styles along its length (e.g. Stern, 1994; Shackleton, 1996; Jacobs et al., 1998; Fritz et al., 2013). Significant portions of the East African-Antarctic Orogen are interpretable as products of an early accretionary tectonic stage between juvenile arc terranes, i.e. the Arabian-Nubian Shield (e.g. Stern, 1994, 2002; Johnson and Woldehaimanot, 2003; Johnson et al., 2011). Other parts are dominated 
by evidence for continent-continent collision (e.g. Muhongo and Lenoir, 1994; Kröner, 2001). The East African-Antarctic Orogen in Antarctica was long interpreted as a typical Himalayan-style continent-continent collision orogeny (Jacobs et al., 1998; Jacobs and Thomas, 2004). However, evidence for significant Tonian juvenile oceanic arc terranes, the so-called Tonian Oceanic Arc Super Terrane (TOAST), were recently recognized in eastern DML. The TOAST has similarities to the ArabianNubian Shield and is interpreted to represent remnants of the Mozambique Ocean (Elburg et al., 2015; Jacobs et al., 2015, 2017).

In this contribution, we present a new large aeromagnetic data set to the south and east of Sør Rondane, eastern DML, surveyed during the austral summers 2013/14 and 2014/15 as part of GEA/WEGAS, a longterm joint project of the German Federal Institute for Geosciences and Natural Resources (BGR) and the Alfred Wegener Institute, Helmholtz Centre for Polar and Marine Research (AWI). The survey returned 40,000 line kilometers of new aerogeophysical data covering an important region in the eastern part of the TOAST and its transition to cratonic Indo-Antarctica. The main objective of this study was to better constrain the eastern and southern extent of the TOAST and to provide estimates for its spatial extent by integrating the new data with existing aerogeophysical data.

\section{Geological-geophysical background of the study area and adjacent regions (from $W$ to $E$ )}

The study area lies in eastern DML, immediately to the south and east of the Sør Rondane Mts. The Sør Rondane Mts. and small scattered nunataks to the west (Fig. 2a) represent the most extensive and relatively well studied outcrops in the region. In the central and eastern part of the study area, the remote Belgica Mts. and Yamato Mts. are much more poorly investigated. Just east of the Yamato Mts., a much better data base exists for the coastal Lützow-Holm Bay region. Most of the excellent geological work in these regions has been completed by the Belgian and Japanese Antarctic Research Programs (e.g. Van Autenboer and Loy, 1972; Shiraishi et al., 2008). The geology of the exposed regions is briefly summarized in the following.

\subsection{Sør Rondane}

The Sør Rondane Mts. are subdivided into three major tectonic units, separated by two major structural discontinuities. The units comprise the NE Terrane and the northern and southern parts of the SW Terrane (e.g. Osanai et al., 2013; Mieth et al., 2014). The NE Terrane is separated from the SW Terrane by the Main Tectonic Boundary, whilst the subdivision of the SW Terrane is achieved across the Main Shear Zone.

The southern part of the SW Terrane consists mainly of a little deformed gabbro-tonalite-trondhjemite-granodiorite complex, which is U-Pb zircon dated at ca. 1000-900 Ma (Kamei et al., 2013; Elburg et al., 2015). Their geochemistry, Sm-Nd and zircon Hf-signature, as well as the lack of older inheritance characterizes these gabbrotonalite-trondhjemite-granodiorite complex as part of a juvenile oceanic arc complex (Elburg et al., 2015). Together with similar rocks in small nunataks to the west, these rocks represent the type locality for the TOAST (Jacobs et al., 2017). Minor crustal additions are still recorded at ca. $770 \mathrm{Ma}$ (Kamei et al., 2013). The northern part of the SW Terrane consists of greenschist to granulite facies metasedimentary and metaigneous rocks, with youngest detrital zircon ages of ca. $700 \mathrm{Ma}$ (Otsuji et al., 2013; Owada et al., 2013). Peak metamorphic conditions are dated at ca. 640-600 Ma and are associated with an anticlockwise PT-path (Adachi et al., 2013). The northern SW Terrane and the gabbro-tonalite-trondhjemite-granodiorite complex are separated by the dextral Main Shear Zone, which represents an important lithospheric structure of Ediacaran to Cambrian age (Ruppel et al., 2015).

The amphibolite- to granulite facies NE Terrane is predominantly composed of metasupracrustal rocks with youngest detrital zircon ages of ca. $750 \mathrm{Ma}$; no basement to these rocks is recognized so far (Shiraishi et al., 2008). U-Pb zircon dating indicates granulite-facies metamorphic overprint associated with a counterclockwise PT-path at ca. 640-600 Ma and retrograde metamorphism at ca. 590-530 Ma, the latter of which is related to orogenic collapse. Contrasting PT-paths on either side of the Main Tectonic Boundary are interpreted to result from thrusting of the NE Terrane over the SE Terrane (Osanai et al., 2013). Rare inherited zircons with Archean and late Mesoproterozoic

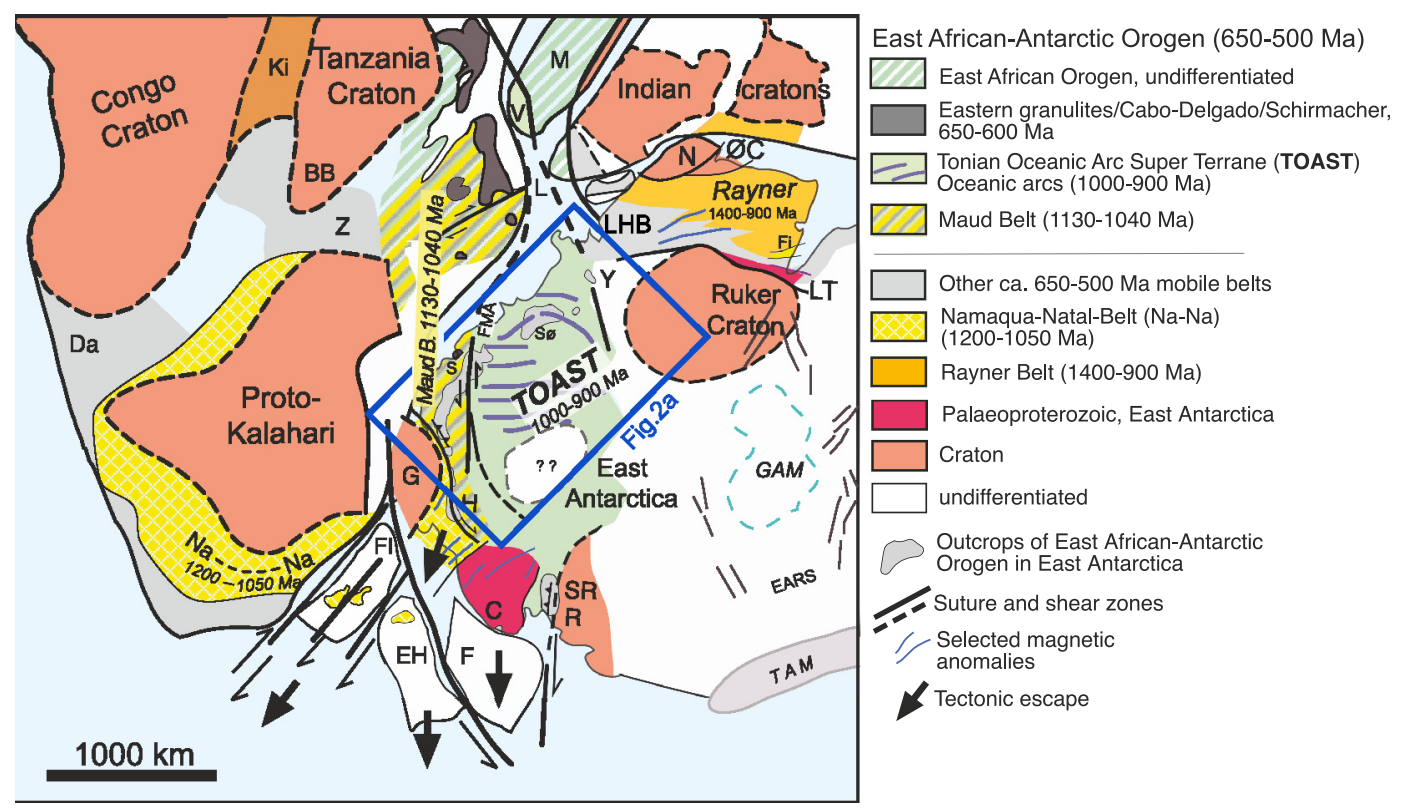

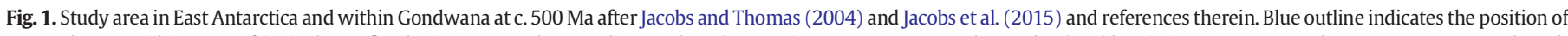

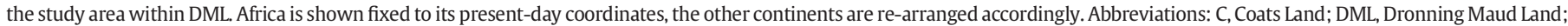

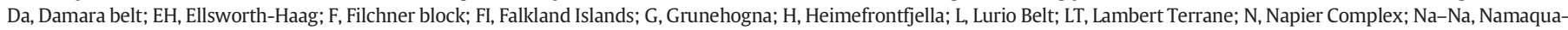

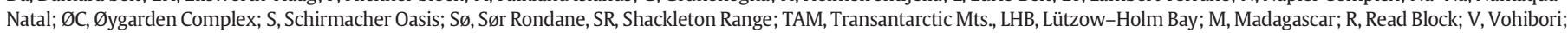
Y, Yamato Mts.; Z, Zambesi belt. 
ages may suggest proximity to a continental source (Elburg et al. (2015). In general, the Sør Rondane Mts. show long-lasting tectonometamorphism and associated magmatism between ca. 650 and $500 \mathrm{Ma}$, which is related to protracted accretion and collision in this part of the East African-Antarctic Orogen (Elburg et al., 2016).

\subsection{Belgica Mts. and Yamato Mts.}

The Belgica and Yamato Mts. are located in the eastern survey area and represent an overall poorly studied region within DML. The geology of Belgica Mts. was first described by Van Autenboer and Loy (1972) as a
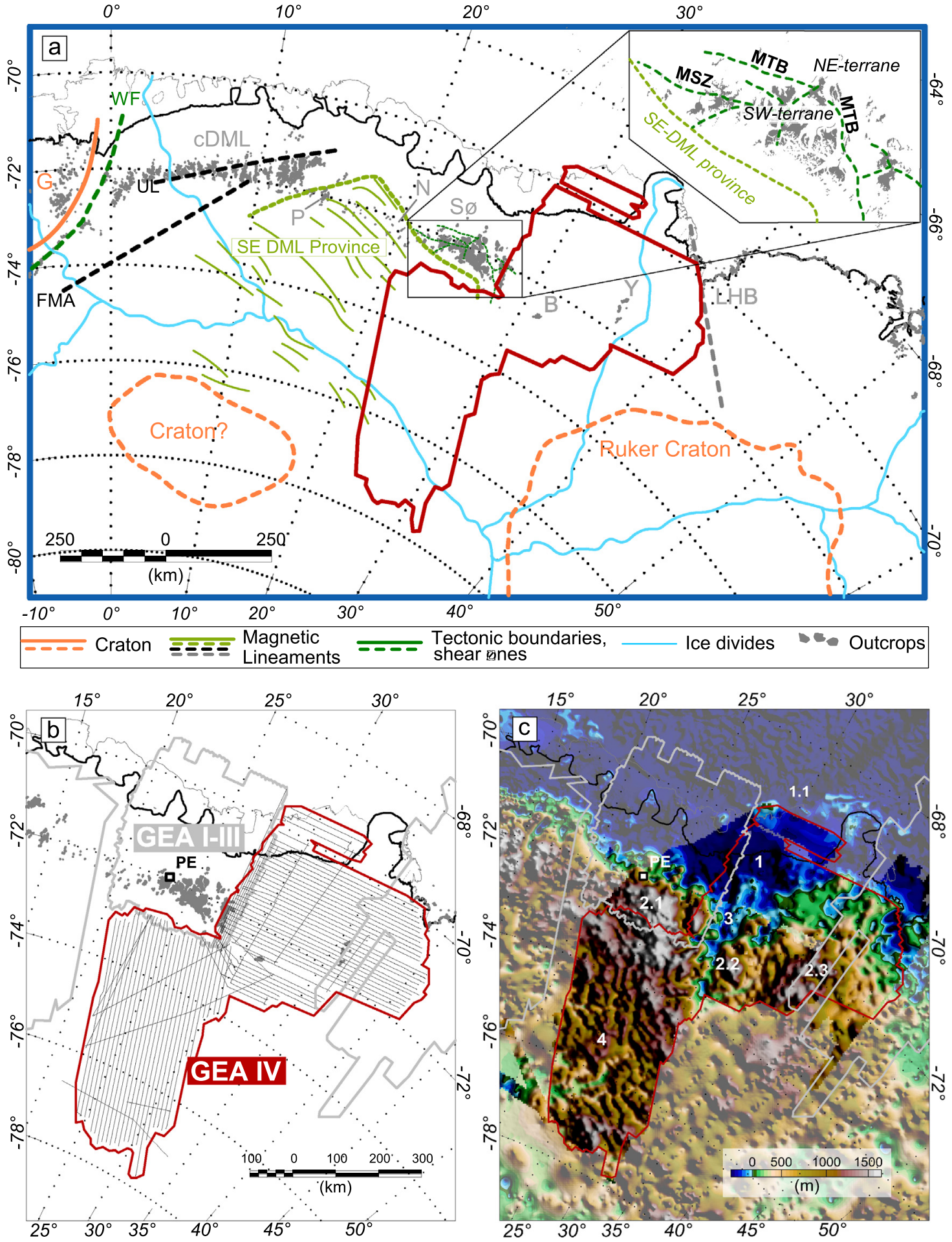

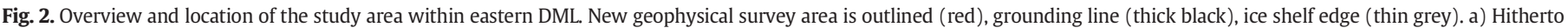

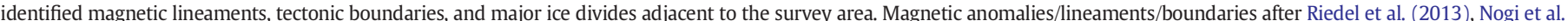

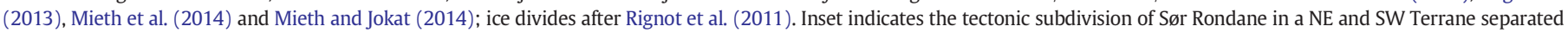

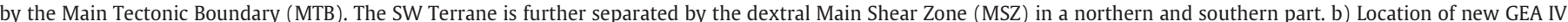

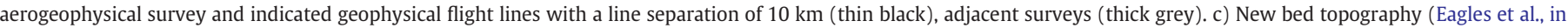

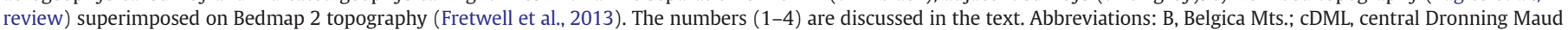
Land; FMA, Forster Magnetic Anomaly; G, Grunehogna; LHB, Lützow-Holm Bay; N, nunataks; P, Payerfjellet; Sø, Sor Rondane; WF, western front of the EAAO; Y, Yamato Mts. 
small isolated mountain massif consisting of migmatised biotitehornblende gneisses intercalated with marbles. The gneisses are intruded by coarser grained granite and two generations of younger dyke systems, which are also of granitic composition. The authors note the close correlation with Sør Rondane.

The Yamato Mts. are characterized by metamorphic rocks, mainly composed of amphibolite-facies quartzo-feldspathic and intermediate gneisses, intermingled with low-pressure granulite facies rocks (cf. Hiroi et al., 1991; Shiraishi et al., 2003). Two thermal events at ca. $620 \mathrm{Ma}$ and ca. $535 \mathrm{Ma}$ may be associated with granulite facies metamorphism and amphibolite facies metamorphism, respectively (Shiraishi et al., 1982; Shiraishi et al., 2003). These ages indicate a similar history as in the Sør Rondane Mts. (Shiraishi et al., 2003). Metamorphic rocks are intruded by voluminous syenites which are considered to have been emplaced during the waning stage of granulite facies metamorphism (Zhao et al., 1995).

Based on sparse protolith age data ( $\mathrm{T}_{\mathrm{DM}}$ model ages), Shiraishi et al. (2008) suggest that the Belgica and Yamato Mts. may represent the easternmost parts of the 'Sør Rondane Terrane'.

\subsection{Lützow-Holm Bay}

The Lützow-Holm Bay Complex in the easternmost part of the study area consists of high-grade metamorphic rocks with increasing metamorphic grade from upper amphibolite-facies in the east to granulitefacies in the southwest (Hiroi et al., 1991). Ultrahigh-temperature metamorphism in the Lützow-Holm Bay Complex was U-Pb zircon dated at ca. 550-520 Ma. (Motoyoshi and Ishikawa, 1997; Shiraishi et al., 1992, 1994, 2003). The southeastern part of the Lützow-Holm Bay Complex is interpreted to have involved the collision of several volcanic arcs and oceanic components with Archean-Palaeoproterozoic crust, as evidenced by $\mathrm{T}_{\mathrm{DM}}$ model ages (Shiraishi et al., 2008). Recent studies suggest a subdivision of the Lützow-Holm Bay Complex into three units (i) a Neoarchean-Early Palaeoproterozoic (ca. $2.5 \mathrm{Ga}$ ) unit in the southern Lützow-Holm Bay Complex, (ii) a Neoproterozoic (ca. $1.0 \mathrm{Ga}$ ) unit of juvenile character in the northern Lützow-Holm Bay Complex, and (iii) a supracrustal unit with fragments of Neoarchean to Neoproterozoic (ca. 2.5, 1.8, and $1.0 \mathrm{Ga}$ ) magmatic arc in the central Lützow-Holm Bay Complex (Tsunogae et al., 2015, 2016; Takahashi et al., 2017).

\subsection{Tonian Oceanic Arc Super Terrane (TOAST)}

The Tonian Oceanic Arc Super Terrane (Jacobs et al., 2015) was recognized by integrating geology and geophysics of the region to the west of the study area. First geophysical evidence for a major discrete crustal block was provided by aeromagnetic data from central DML (Mieth and Jokat, 2014). These authors identified a major distinct magnetic province (SE DML province) east of the Forster Magnetic Anomaly and to the south of central DML. This province is characterized by NW-SE trending, narrow (10-20 km) and elongated (120-200 km) positive, small amplitude anomalies (50-100 nT) within a rather weak magnetic anomaly field/background (grey lines). This newly identified block was then interpreted as an orogenic belt of unknown age, whereas the structures were inferred to predate the Forster Magnetic Anomaly (Mieth et al., 2014).

The first geological evidence for the history of the TOAST documents a main phase of subduction in the form of juvenile magmatic rocks from around 995-975 Ma, followed by a younger phase around 960-925 Ma in the SW Terrane of Sør Rondane (Kamei et al., 2013; Elburg et al., 2015). Study of the mostly ice-covered area between central DML and Sør Rondane also revealed geochronological ages of ca. 1000-900 Ma for juvenile basement and new geochemistry data that are very similar to the SW Terrane of Sør Rondane (Elburg et al., 2015; Jacobs et al., 2015). The geological findings from between central DML and Sør Rondane correlate spatially with the aeromagnetic SE DML province
(Mieth and Jokat, 2014) and suggest that the latter represents an extensive region of Neoproterozoic oceanic arcs, interpreted as remnants of the Mozambique Ocean (Elburg et al., 2015; Jacobs et al., 2015).

Further evidence for the extent of the TOAST and the geologic nature of its distinct magnetic domains has been obtained indirectly, by analyses of moraine material drained from the interior of East Antarctica. The north-directed ice flow in the region occurs within a catchment that is limited by a major ice divide ca. $800 \mathrm{~km}$ to the south of the Sør Rondane Mts. (Rignot et al., 2011; Jacobs et al., 2017). Analyses of a large detrital $\mathrm{U}-\mathrm{Pb}$ zircon data set from glacial drift sourced out of this catchment strengthens the interpretation that the TOAST extends at least as far as the ice divide (Jacobs et al., 2017). A significant Stenian age peak correlates with juvenile grey granodioritic gneisses that represent a precursor of the TOAST. A few Palaeoproterozoic zircon grains from the easternmost samples may indicate the vicinity to a craton farther to the east, e.g. the Ruker Craton (Fig. 2a).

The western extent of the TOAST is delineated by the Forster Magenetic Anomaly, at which it is juxtaposed with Grenville-aged rocks of the Maud Belt (Riedel et al., 2013; Jacobs et al., 2015). The southern and eastern extents of the TOAST are so far very speculative.

\section{Data acquisition and processing}

Airborne geophysical data were collected by using the AWI Basler aircraft Polar 5 and 6 . Two target areas south $\left(73^{\circ} \mathrm{S} / 21^{\circ} \mathrm{E}\right.$ to $77.5^{\circ} \mathrm{S} /$ $\left.32^{\circ} \mathrm{E}\right)$ and east $\left(70.5^{\circ} \mathrm{S} / 28^{\circ} \mathrm{E}\right.$ to $\left.72^{\circ} \mathrm{S} / 40^{\circ} \mathrm{E}\right)$ of Sør Rondane were surveyed from the Belgian Princess Elisabeth Station (PE). These areas are attached to previous surveys of the GEA I-III campaigns covering Sør Rondane and the ice shelves north of it (Mieth et al., 2014). The survey lines were flown with a flight line spacing of $10 \mathrm{~km}$ in N-S direction south of Sør Rondane and in an E-W direction east of it (Fig. 2b). In total, close to 40,000 line kilometers of radar, gravity and magnetic data were collected. Radar and gravity data are presented and interpreted in detail (Eagles et al., in review).

The acquisition of magnetic data was carried out with a Scintrex Cs-3 caesium vapour magnetometer mounted in a tail boom. A fuselagemounted three-component Billingsley TFM 100 fluxgate magnetometer was used for magnetic compensation. Diurnal variations of the magnetic field were recorded with a magnetic base station deposited near the airfield of Princess Elisabeth station. Records from a year-round magnetic base station at Syowa were used for correction of data gaps and comparison. Processing of magnetic data was carried out using the geophysical software Oasis Montaj by Geosoft. The work flow included de-spiking, core-field and diurnal variation corrections as well as statistical and micro-levelling procedures. The final data were gridded with a grid cell size of $3 \mathrm{~km}$. In order to simplify the interpretation of magnetic anomalies, the magnetic pattern was transformed by a grid-based reduction to the pole.

Advanced filtering and transformation techniques including upward continuation, tilt derivative, pseudo-gravity and the analytical signal were applied to the magnetic data to enhance prominent magnetic anomaly patterns. Upward continuation attenuates high wavenumber anomalies associated with shallow magnetic sources and enhances regional magnetic anomalies resulting from deeper sources (Blakely, 1995). The upward continuation was calculated to an observation level of $10 \mathrm{~km}$ above sea level. Calculation of the tilt derivative was completed using the pole reduced magnetic anomaly grid, and can be used to enhance positive magnetic lineaments and to map structural trends (Miller and Singh, 1994; Verduzco et al., 2004). Peaks in the maximum horizontal gradient of pseudo-gravity are helpful in locating the edges of magnetic source bodies and magnetic lineaments (Cordell and Grauch, 1982; Blakely and Simpson, 1986). Further, the analytic signal and calculation of located Euler depth can be used to locate the edges and corresponding depths of magnetic source bodies (Roest et al., 1992). 


\section{Results}

\subsection{Bed topography}

The bed topography is subdivided into a northern and southern part, separated by a seawards-facing escarpment (Fig. 2c, Eagles et al., in review). A deep flat subglacial plain characterizes the northern part whereas the southern part hosts a south dipping low-relief subglacial landscape. Coastal areas (1) are characterized by topographic elevations below sea level (bsl) reaching down to $3000 \mathrm{~m}$ bsl (1.1). The E-W trending mountain range, whose seawards-facing escarpment hosts Sør Rondane (2.1) exhibits an average altitude of $2000 \mathrm{~m}$ above sea level (asl) with highest peaks reaching ca. $3000 \mathrm{~m}$ asl. Further subglacial topographic highs surround the outcropping Belgica Mts. (2.2) and Yamato Mts. (2.3). Sør Rondane and the Belgica Mts. are separated from one another by a NNW-SSE trending trough (3) underlying the West Ragnhild glacier. The hinterland topography of eastern DML (4) has an average altitude of $900 \mathrm{~m}$ asl. and is characterized by deeply incised v-shaped valleys reaching up to $110 \mathrm{~m}$ asl. This WSW-directed structures are interpreted as a pre-glacial fluvial landscape only lightly modified and preserved underneath a cold-based ice sheet (Eagles et al., in review).

\subsection{Airborne magnetics}

By combining the new magnetic data with those from the first three GEA campaigns (GEA I-III, Mieth et al., 2014), we generated new aeromagnetic anomaly maps and enhancements for the area across and adjacent to Sør Rondane in the south and east (Figs. 3, 4 and 5). Magnetic data and their enhancements were used to identify magnetic domains,
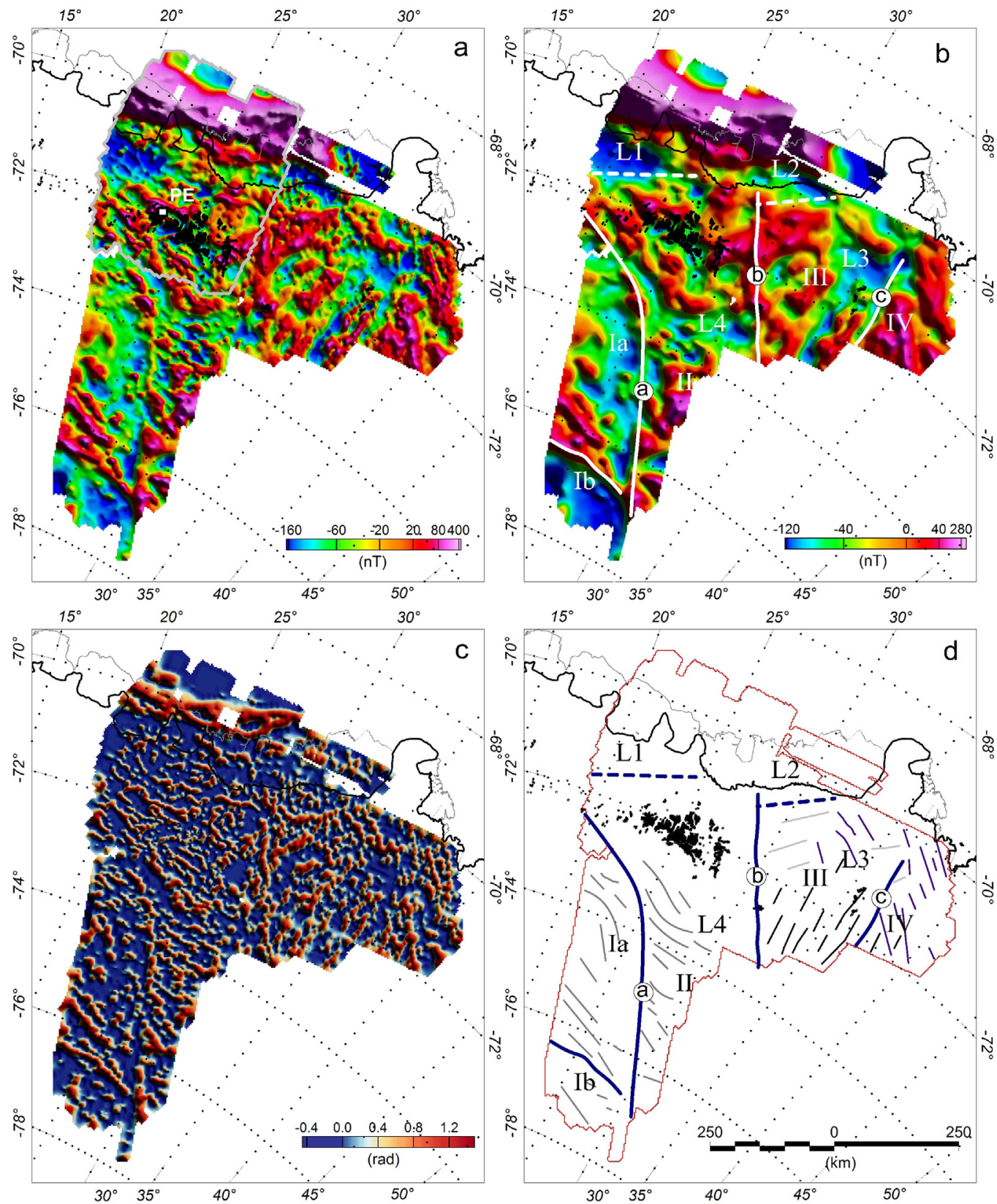

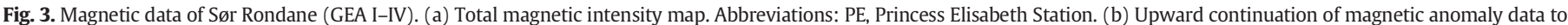

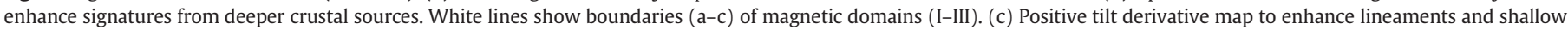

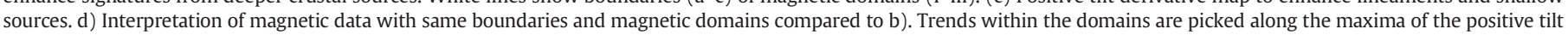
derivative. Outcrops (black dots), and the location of the survey (red outline) are indicated. All maps show the grounding line (thick black), and the shelf ice edge (thin grey). 

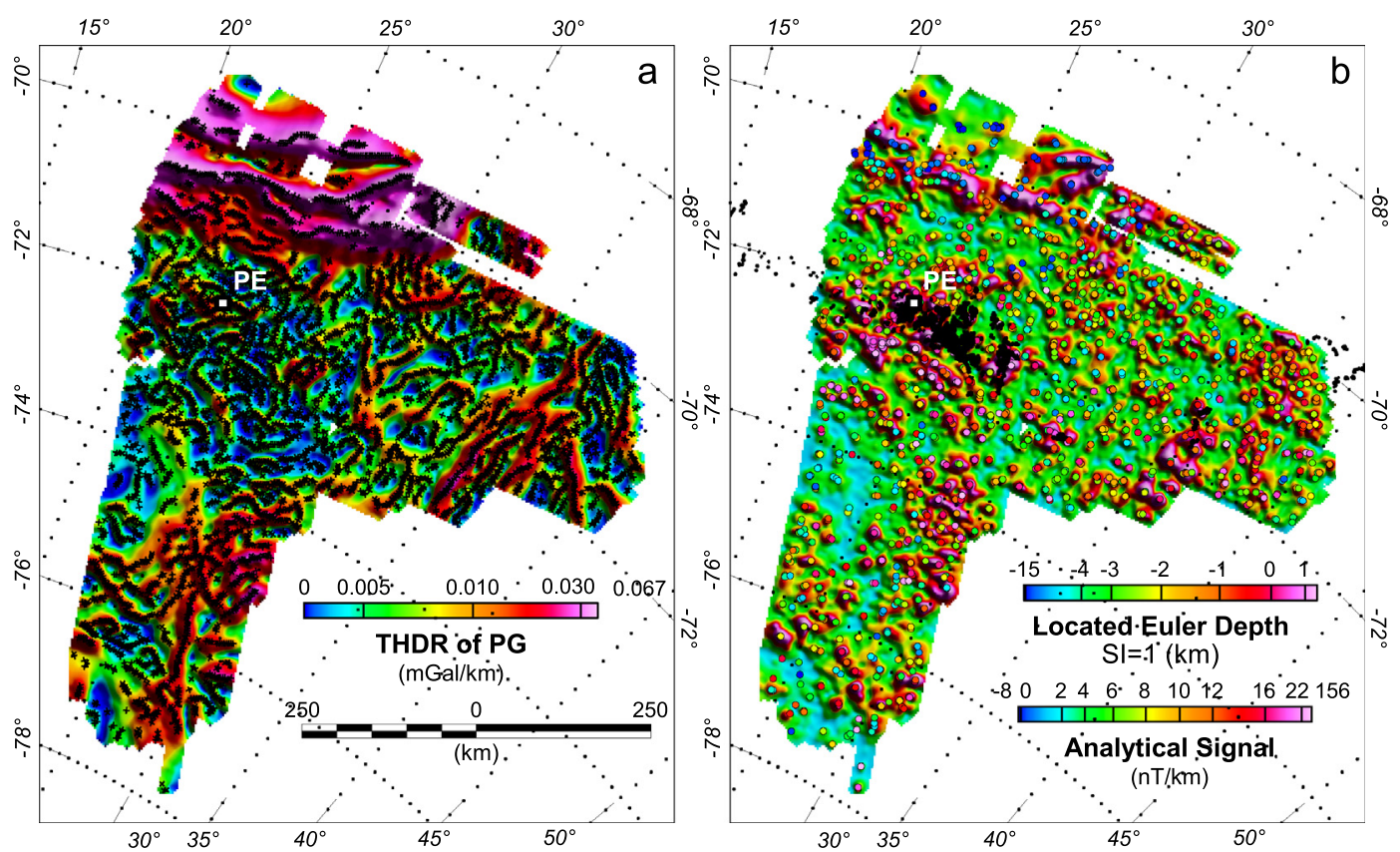

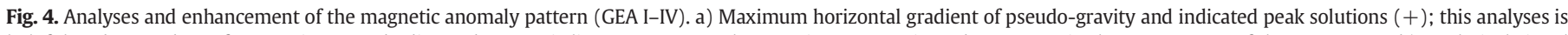

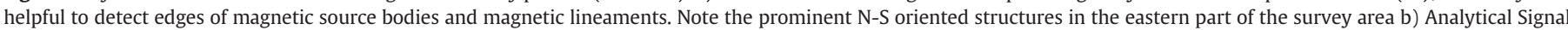
overlain by Located Euler Depth solution with $\mathrm{SI}=1$ (dyke and sill structures).

major structural trends and possible magnetic sources. The continuation of the observed magnetic anomaly pattern is indicated in Fig. 6. Here, data of this study and the former GEA I-III surveys over Sør Rondane are superimposed on the VISA magnetic data compilation of DML in the west (Mieth and Jokat, 2014), and the lower-resolution ADMAP dataset (Golynsky et al., 2007) in the east. The magnetic anomaly pattern south and east of Sør Rondane is characterized by moderate amplitudes between -225 and $+390 \mathrm{nT}$ (Fig. 3a). The highest anomaly values can be observed offshore, to the far east of Yamato Mts. and to the SSE of Sør Rondane. Negative magnetic anomalies occur close to the coast as well as in the southernmost part of the survey area.

The analyses of aeromagnetic data and their enhancements, together with their correlations to magnetic anomaly data from adjacent areas, lead to the identification of four magnetic domains ('I-IV'), separated by three major boundaries/lineaments ('a-c'), as labeled in Fig. 3:
Domain 'I' is characterized by positive and elongated NW-SE trending magnetic anomalies with amplitudes of c. 50-100 nT. This domain is further subdivided in a northern subdomain 'Ia' with positive magnetic anomalies reaching up to $300 \mathrm{nT}$ and a southern subdomain 'Ib' with maximum values of only $40 \mathrm{nT}$. The division into two subdomains is apparent in the long wavelength anomaly pattern indicated by the upward-continued magnetic anomaly data (Fig. 3b), whereas the tilt derivative map emphasizes the subdomains' short wavelength trend similarities (Fig. 3c). The magnetic low of subdomain 'Ib', with minimum values of $-200 \mathrm{nT}$, is also observable in the older low-resolution data compiled for ADMAP (Golynsky et al., 2007). The northeastern extent of domain 'I' is well confined by boundary 'a', which is characterized by a curved, approximately NNW-SSE directed, and partly discontinuous positive magnetic anomaly. This lineament can be traced in the survey area over ca. $550 \mathrm{~km}$. Upward continued magnetic anomaly data
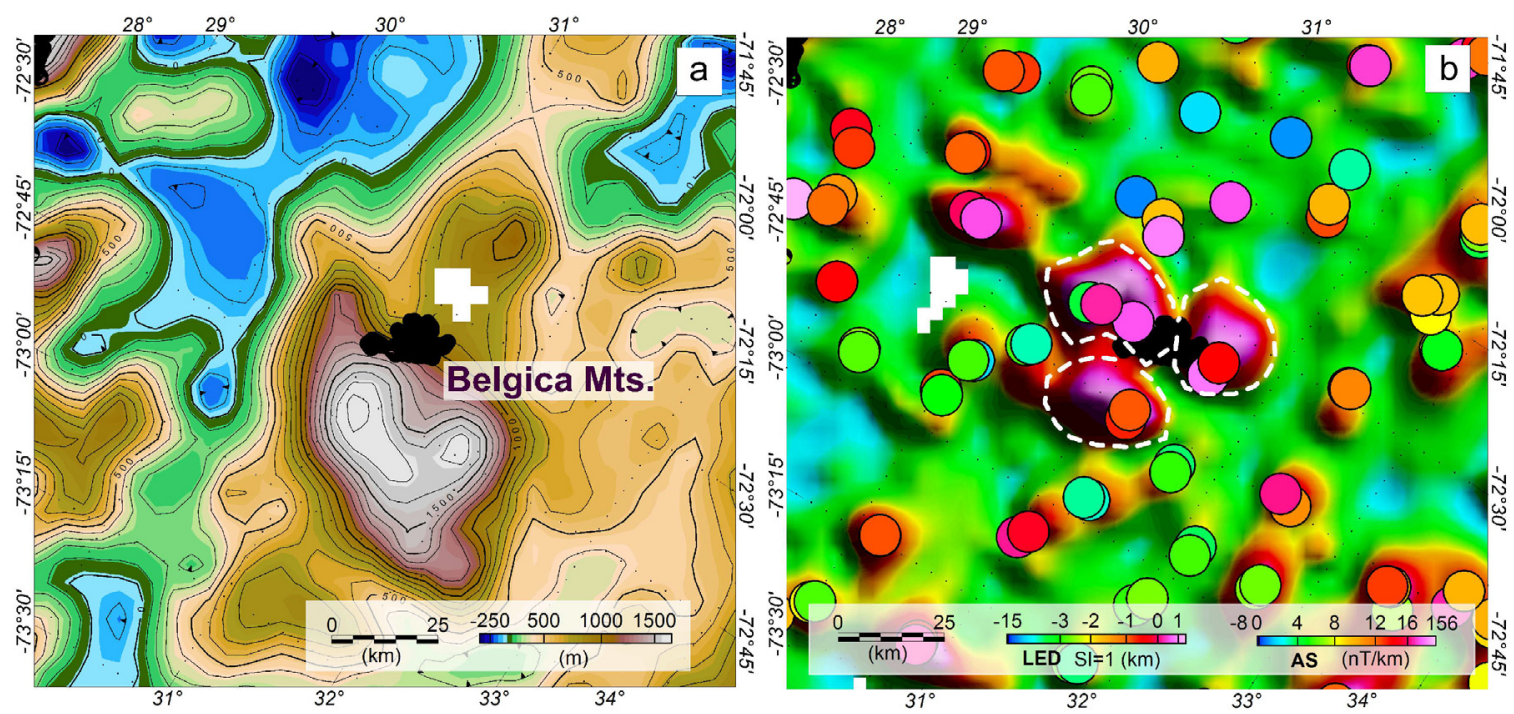

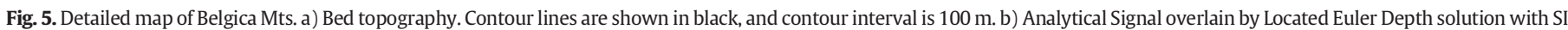
$=1$ (dyke and sill structures). Analytical Signal indicates three circular shaped structures with shallow sources most likely related to intrusive bodies. 

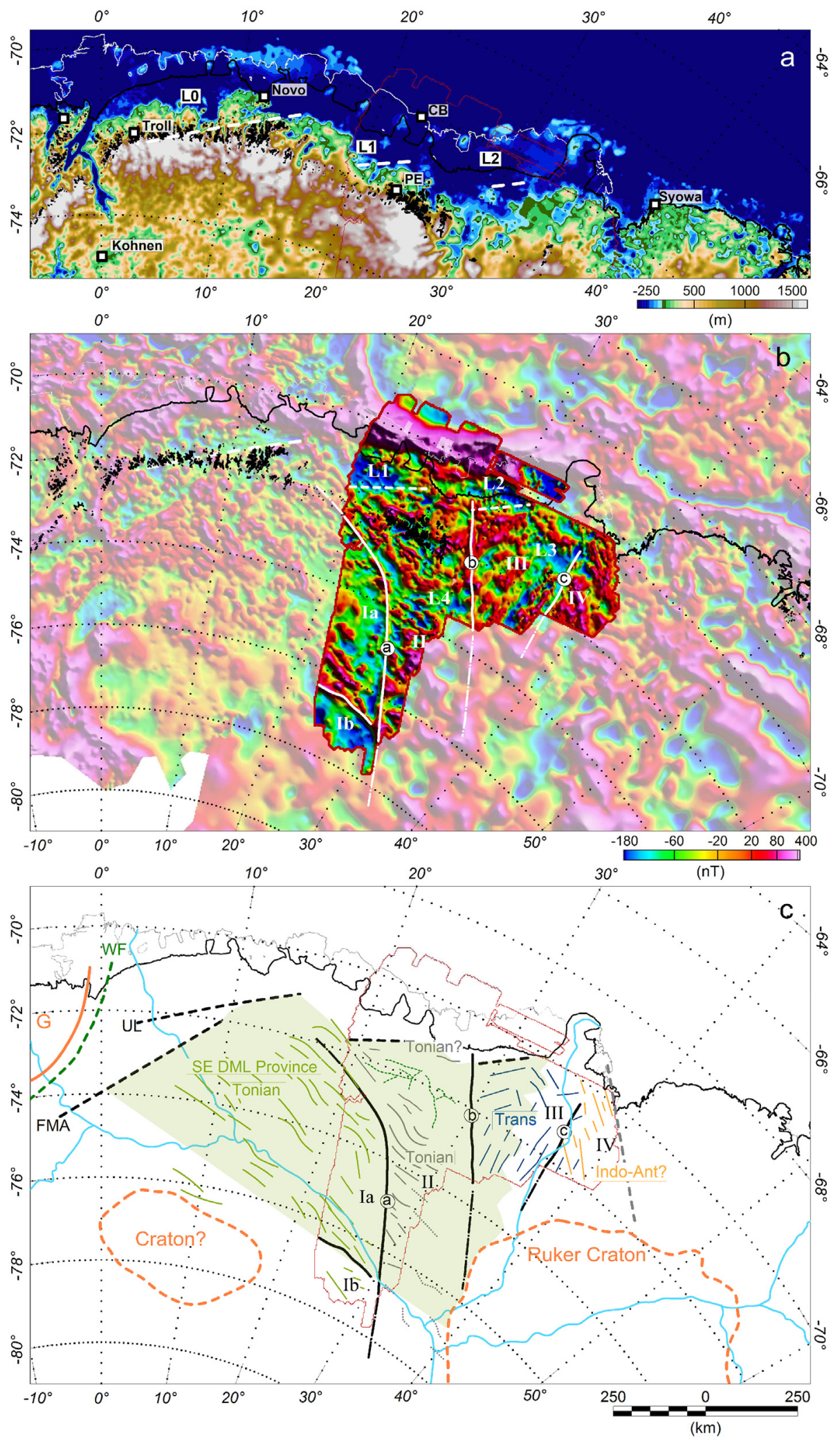

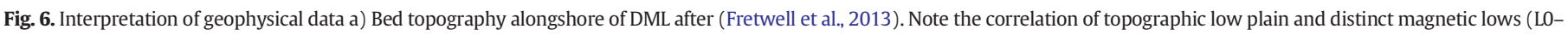
L2); b) Magnetic data and its continuation beyond the survey area. GEA I-IV survey is superimposed on a compilation of magnetic data from the AWI-DML compilation in the west (Mieth and Jokat, 2014) and from ADMAP data (Golynsky et al., 2007) in the east. White lines show boundaries (a-c) of magnetic domains (I-III). (c) Interpretation of combined magnetic and geological data. Main structural trends of magnetic domains are indicated within the domains with thin lines. Black lines show boundaries (a-c) of magnetic domains (I-III). Colors refer to individual domains. Boundaries are extrapolated based on magnetic compilation, shown in c). Green region indicates the minimum anticipated extend of the TOAST as discussed in the text. For abbreviation and legend see Fig. 2. 
support the definition of boundary 'a', which is indicated by a change from low (domain 'I') to higher magnetic values (domain 'Il'). The curvilinear trend of this major lineament can be well observed in the tilt derivative map (Fig. 3c), which highlights how its orientation changes from NW-SE in the northern part to NNW-SSE in the southern part. Magnetic anomalies west and east of boundary 'a' appear to be dragged into the curvilinear boundary, indicating a dextral sense of shear.

Domain 'II' is located east of boundary 'a' and shows similar curved, elongated positive NW-SE directed magnetic anomalies with amplitudes of $50-150 \mathrm{nT}$ and values up to $380 \mathrm{nT}$. This domain is characterized by higher frequency magnetic anomalies than those in domain 'I'. Elongated (30-50 km), positive magnetic anomalies show a NW-SE orientation within domain 'II'. Further, the upward continuation of magnetic anomaly data reveals a distinct ENE directed magnetic low to the SE of Sør Rondane (L4). Boundary 'b' is the western boundary of domain 'Il' with domain 'II' (Fig. 3d). This boundary is characterized by a positive NE-SW trending magnetic lineament that is approximately parallel to that of the southern part of boundary 'a'. This lineament is very apparent in the tilt derivative map (Fig. 3c). The ADMAP data suggest that boundary 'b' can be traced beyond the survey area to continue significantly farther inland (Fig. 6).

Examination of the magnetic anomaly data, their upward continuation and tilt derivative, reveals a complex anomaly pattern with varying amplitudes, intensities, and trend directions in magnetic domain 'III'. High frequency, negative magnetic anomalies dominate the coastal area. Magnetic lows seem to be well defined in the upward continued anomaly data (L2, L3). Positive magnetic anomalies (up to $240 \mathrm{nT}$ ) are dominated by a N-S directed trend in Fig. 3a, but SW-NE and NW-SE directed trends are also indicated by the tilt derivative. Boundary ' $c$ ' is located between domains 'III' and 'IV' east of two distinct, parallel N-S trending positive magnetic anomalies parallel to the outcrop of the Yamato Mts.

Domain 'IV', east of boundary ' $c$ ', is dominated by positive magnetic anomaly values reaching up to $200 \mathrm{nT}$. The long wavelength anomaly pattern in the upward continued map indicates a distinct area of high values (Fig. 3b). The tilt derivative map indicates mainly NNW-SSE directed trends of positive magnetic anomalies. Similar trends are subordinately present in domain 'III'.

Fig. 4 illustrates further enhancements of the magnetic anomaly data, enabling depth estimates of magnetic source bodies. The maximum horizontal gradient of the pseudo-gravity enhances boundaries 'a'-'c' and indicates similar trends within the individual domains as the tilt derivative. As such, NW-SE oriented structures are present in domains 'I' and 'II', with the trends in domain II more subdued. The map significantly enhances the N-S oriented structures of domain 'III' and suggests a continuous magnetic source along boundary ' $c$ ' in the east. The change to a NNE-SSW orientation of possible magnetic source bodies is also evident within domain 'IV'. Located Euler depths are calculated and superimposed on the calculated analytical signal in Fig. 4b. Relatively shallow depth solutions highlight the areas across and to the SW of Sør Rondane (within domain 'II'), Belgica Mts. and Yamato Mts. In contrast, the coastal area is dominated by deep seated depth solutions for possible source bodies (up to $-15 \mathrm{~km}$ ).

\section{Interpretation and discussion}

The analyses of new aeromagnetic data and their enhancements provide new evidence for the structural architecture of eastern DML. In this section, the new data are correlated with adjacent aeromagnetic data and integrated with exposure information from Sør Rondane and the Belgica and Yamato Mts. The correlation and integration of geophysical and geological data and their presumed extrapolation provides new evidence for the subglacial tectonic framework and improves knowledge of the spatial extent of the TOAST in eastern DML (Fig. 6).
5.1. Spatial extent of the SE DML province (subdomain 'Ia', boundary ' $a$ ', domain 'II')

Subdomain 'Ia' is characterized by positive, moderate-amplitude, elongate, NW-SE trending magnetic anomalies within an overall subdued magnetic anomaly field. The same characteristics account for the SE DML province. Based on this, subdomain 'Ia' is interpreted as the eastward continuation of the SE DML province (Mieth and Jokat, 2014). Ground-truthing of subdomain 'Ia' is possible at Payerfjellet (Steingarden). Here, U-Pb zircon dating of grey gneiss with igneous protolith (gabbro-tonalite-trondhjemite-granodiorite complex) revealed a crystallization age of c. $980 \mathrm{Ma}$ and two metamorphic ages of c. $630 \mathrm{Ma}$ and $560 \mathrm{Ma}$. The gabbro-tonalitetrondhjemite-granodiorite complex is interpreted to be part of a juvenile oceanic arc complex (part of the TOAST) with a protracted metamorphic overprint (Jacobs et al., 2015). Subdomain 'Ia' is bound to the east by boundary 'a', which is represented by a $700 \mathrm{~km}$ long, curvilinear, partly broken positive magnetic lineament (Fig. 6b, c; including adjacent areas).

Domain 'II' has generally higher magnetic values at long wavelengths than domain Ia. Domain 'II' also shows shorter (30-50 km) positive magnetic anomalies at higher frequencies. Despite this, the trend direction of the magnetic anomalies is similar to those in subdomain Ia. Sør Rondane and scattered nunataks to the west crop out at the northern tip of domain 'Il'. Southwest Sør Rondane is mainly composed of a gabbro-tonalite-trondhjemite-granodiorite complex of Tonian age and clearly indicates juvenile crust that has evolved within an oceanic arc system (Jacobs et al., 2015). The northeastern part of Sør Rondane consists of high-grade metasedimentary rocks with no exposed basement. Detrital zircons of the metasedimentary rocks provide only minor evidence for an older, pre-Mesoproterozoic provenance (e.g. Shiraishi et al., 2008; Kitano et al., 2016). This is in line with U-Pb zircon analyses of glacial drift from the southern side of Sør Rondane, which also give no evidence for any pre-1100 Ma basement. However, the glacial drift shows an oldest Stenian age peak (1100-1000 Ma) that is largely unknown from exposures and which is the only evidence for pre-Tonian rocks in this region (Jacobs et al., 2017).

Based on the lack of pre-Stenian age components of exposed rocks in domain 'II' and the similarities in magnetic anomaly pattern, we suggest that domain II represents a further eastern continuation of the TOAST. The similarity of U-Pb zircon ages either side of boundary 'a' may indicate that it separates either two different Tonian arc complexes or different crustal levels of a single arc complex. Therefore, boundary 'a' may represent either a terrane boundary or a major shear zone. The anomaly patterns of subdomains 'Ia' and 'II' can be interpreted in terms of dextral simple shear along boundary 'a'. Major dextral transcurrent shearing is also recorded along the Main Shear Zone in the SW Sør Rondane Mts.

\subsection{Southern extent of the TOAST (subdomain, 'Ib')}

The magnetic anomaly pattern of subdomain 'Ib' is significantly different than that in subdomain 'Ia' because of its overall negative anomaly pattern. Despite this, at shorter wavelengths its SE trend directions are very similar to those in subdomain 'Ia'. The lack of exposures prevents ground-truthing of subdomain 'Ib'. Since this region is located south of the ice divide, it is unlikely that domain 'Ib' is represented in samples of the glacial drift analysed by Jacobs et al. (2017). Interpretations of subdomain 'Ib' are thus speculative. Among many possibilities, it may represent (1) a continuation of the TOAST, whose different magnetic signature may be attributed to the contrasting composition of a probably older oceanic arc complex, or (2) a different crustal province of possibly older or cratonic nature, consistent with its negative magnetic anomaly pattern (cf. Grunehogna Craton). 
5.3. Minimum eastern extent of the TOAST (boundaries ' $b$ ' $\mathcal{E}$ ' $c$ ', domain 'III' $\mathcal{E}^{\prime}(I V ')$

The Belgica Mts. appear to crop out along the newly defined boundary 'b', which separates domains 'II' and 'III'. Boundary 'b' can be traced for ca. $450 \mathrm{~km}$ in the present dataset. On the regional ADMAP compilation this magnetic lineament appears to continue for another $300 \mathrm{~km}$ and to the proposed western rim of the Ruker Craton Golynsky et al. (2007) (Fig. 6b, c). The magnetic anomaly pattern of domain 'III' differs clearly from the typical TOAST signature and exhibits a more complex structure with differently oriented magnetic structures. The calculated positive tilt derivative revealed three major trend directions. $\mathrm{N}-\mathrm{S}$ directed trends are also significantly present in the THDR of pseudogravity at the eastern side of domain 'III', which may indicate elongated source bodies or structures. Additionally, the N-S trends are also observed in the bed topography as elevated ridges close to the Yamato Mts. and may suggest a major topographic influence on the geometry of the magnetic anomaly source.

Geological observations in the Belgica Mts. indicate similarities with the Teltet-Vengen Group in the northern portion of the SW-Terrane of Sør Rondane (Van Autenboer and Loy, 1972). The Belgica Mts. reveal migmatitic bt-hbl-gneisses of mainly granitic composition. They are intruded by lenses and streaks of coarse grained granite. Here, the calculated analytical signal indicates three major circular shaped magnetic complexes (Fig. 5). Euler depth solutions show it is likely that these anomalies represent intrusive bodies with relatively shallow sources at levels between approximately $1000 \mathrm{~m}$ below and $800 \mathrm{~m}$ above sea level. Geochronological investigations at the Belgica Mts. have revealed one Nd-model age of approximately $0.94 \mathrm{Ga}$. This age correlates reasonably well with the average $\mathrm{T}_{\mathrm{DM}}$ ages of $1.08 \mathrm{Ga}$ observed in Sør Rondane. Amphibolite facies metamorphism was U-Pb zircon dated at c. $660 \mathrm{Ma}$ (Shiraishi et al., 2008). Similar metamorphic ages of ca. 640-600 Ma are also observed in the Sør Rondane region. Although these similarities are based on very sparse data, this may indicate that the Belgica Mts. and domain 'III' are both underlain by juvenile Neoproterozoic crust. Similarly, only very sparse geological information is available from the Yamato Mts. ca. $200 \mathrm{~km}$ further east. Here, the Late Neoproterozioc/ Early Palaeozoic metamorphic rocks are intruded by major granitoids dated to $620 \mathrm{Ma}$ and $530 \mathrm{Ma}$ and provide one Nd-model age of $1.3 \mathrm{Ga}$. This model age is transitional between the slightly younger model ages in Sør Rondane to the west and the usually significantly older model ages in the Lützow-Holm Bay region to the east. Samples of the Lützow-Holm Bay region show two groups of $\mathrm{T}_{\mathrm{DM}}$ values between 0.87 and $2.70 \mathrm{Ga}$, with a major mode at $1.0-1.25 \mathrm{Ga}$ and a smaller mode at 2.29-2.70 Ga (Shiraishi et al., 2008). The older mode is not evident to the $\mathrm{W}$ of Yamato Mts. Beyond this hint, there are no further indications of the age or origin of older crust in the basement underlying the Yamato Mts.

A significant change of the magnetic anomaly pattern and trend of magnetic structures can be observed east of the Yamato Mts. and boundary ' $c$ '. This N-S trending boundary can be traced farther $\mathrm{S}$ in the ADMAP data and, like boundary ' $b$ ', appears to terminate at the margin of the Ruker Craton (Fig. 6b, c). The same structure has previously been interpreted in the ADMAP data as the western limit of the IndoAntarctic craton by Osanai et al. (2013). If this interpretation is correct, the domain 'II' could represent a transition zone from Tonian arc terranes into the Indo-Antarctic continent. This interpretation is supported by the complex magnetic anomaly pattern, which may be expected in a complicated contact zone.

Domain 'IV' is located at the eastern margin of the survey area and is characterized by SSE directed magnetic anomalies of higher amplitudes, which coincide with elevations in the bed topography. This domain correlates with the geologically characterized southern Neoarchean-Early Palaeoproterozoic (ca. $2.5 \mathrm{Ga}$ ) unit of the Lützow-Holm Bay Complex, also referred to as Shirase microcontinent (Tsunogae et al., 2016; Takahashi et al., 2017). It is therefore different to domain 'III' and may well represent the western margin of Indo-Antarctica. The edge of the survey area coincides with a major NW-SE directed negative magnetic lineament (Nogi et al., 2013).

\subsection{Coastal magnetic low ( $L O-L 2)$}

The coastal region between the escarpment and the continental margin is characterized by prominent long-wavelength magnetic lows, labeled L0, L1 and L2 from west to east (Fig. 6a). Field variation within the lows is relatively subdued, suggesting deep and/or weak magnetic sources. Each of the anomalies is offset dextrally from its neighbours along zones that trend SE, parallel to the very earliest fracture zones in the oceanic crust offshore (Eagles and König, 2018). These observations raise the possibility that the magnetic lows and their offsets represent the basement of a chain of sedimentary basins and crustal-scale transfer zones, consistent with their locations at the extended continental margin formed during Gondwana breakup. Looking further inland, however, it is clear that the two proposed transfer zones also coincide with the marginwards projections of boundaries 'a' and 'b', both of which are suggested above to have accommodated dextral shear in Pan-African escape tectonics (Ruppel et al., 2015). With this observation, therefore, it is possible to interpret the influence of pre-existing (Pan-African and TOAST) structures on the location and segmentation of the plate boundary formed during Gondwana breakup.

\subsection{Spatial extent of the TOAST}

Integrating geology and geophysics in this region allows to estimate the geographical range of the TOAST. To the west, the Forster Magnetic Anomaly is thought to mark the TOAST's minimum western extent (Fig. 2; Jacobs et al., 2017). West of the Forster Magnetic Anomaly, typical Late Mesoproterozoic Maud Belt type crust with equivalents in the African Namaqua-Natal Belt is juxtaposed against Early Neoproterozoic juvenile crust of the TOAST.

The southern extent of the TOAST is less well constrained. We consider the boundary between domains 'Ia' and 'Ib' to be the minimum southern extent of the TOAST. However, as speculated above it is possible that domain 'Ib' may still represent components of the TOAST, and the further southern extent of 'Ib' is difficult to interpret in the ADMAP compilation, which is based on very sparse data.

To the east, domain 'Il' can be confidently assigned to the TOAST and lineament 'b' thus forms its minimum eastern boundary. Alternatively, the TOAST could well continue into a transitional zone in domain 'III'. The rarely-visited and sparsely-studied Belgica and Yamato Mts. allow for ground-truthing of domain 'III', making them a key region for further geological and geochemical studies.

The minimum northern extent of the TOAST is considered as the Main Tectonic Boundary with the SW-Terrane as its type locality. Based on the lack of pre-Neoproterozoic basement and minor preNeoproterozoic detrital zircon provenance, we suggest to also include the NE-Terrane as part of the TOAST. Therefore, the northern extent is most likely defined by the southern boundaries of the coastal magnetic lows (L1 and L2). The typical anomaly pattern of the TOAST with its SEstriking parallel positive magnetic anomalies differs clearly from the coastal magnetic lows. If we restore the region by reverting the dextral shear component, then the southern margin of L1 and L2 would line up with the Ulvetanna Lineament (LO). At this stage, it is highly speculative what the coastal magnetic lows represent.

Considering the boundaries described for the TOAST above, its minimum extent can be estimated as $475,000 \mathrm{~km}^{2}$. Including the proposed transitional areas, this might be enlarged to $550,000 \mathrm{~km}^{2}$. This area represents approximately $5 \%$ of East Antarctica and is comparable to the area of the Antarctic Peninsula with c. $525,000 \mathrm{~km}^{2}$ (including Graham and Palmer Land), a major composite arc terrane that represents accretion and amalgamation of juvenile crust at the margin of Antarctica over a period of at least 200 Myrs, comparable in duration to the Tonian 
period and proposed (1100-900 Ma) amalgamation of both the TOAST and its Stenian precursor.

\section{Summary and conclusions}

40,000 line kilometers of new aeromagnetic data from southern and eastern Sør Rondane and their integration with surface geology provide new insights about the southern and eastern extents of the Tonian Oceanic Arc Super Terrane (TOAST).

- Interpretation of new and existing aeromagnetic data from DML under constraints from surface geology reveals the TOAST to consist of two or more major arc complexes separated across lineaments, one of which we interpret as a major shear zone with a probable dextral sense of movement and a possible Pan-African age.

- We identified an area of ca. $500,000 \mathrm{~km}^{2}$ to be the minimum extent of the TOAST, corresponding to at least $5 \%$ by area of East Antarctica. This area is comparable to that of the Antarctic Peninsula, a juvenile composite arc that amalgamated over a similar duration during Phanerozoic times. The TOAST thus represents significant crustal addition during the assembly of East Antarctica.

- Our data suggest an eastward continuation of the TOAST at least until the Belgica Mts. The magnetic anomaly pattern can be interpreted to imply the presence of a transitional area between Belgica Mts. and the Lützow-Holm Bay region, separating the TOAST from the IndoAntarctic craton.

- The southern minimum extent of the TOAST lies ca. $800 \mathrm{~km}$ inland of Sør Rondane at the boundary to a region of strongly negative magnetic anomalies.

\section{Acknowledgements}

This study was part of the collaborative research program "Geodynamic Evolution of East Antarctica" (GEA) of the German Federal Institute of Geosciences and Natural Resources (BGR) and "West/East Gondwana Amalgamation and Separation" (WEGAS) of the Alfred Wegener Institute Helmholtz, Centre for Polar and Marine Research (AWI).

We thank the science and flight crews of AWI-Polar aircraft for their scientific and technical support. Many thanks to Tobias Binder, Veit Helm, the technicians of AWI and FIELAX, Wayne Hewison of Canadian Microgravity, and the pilots and crew of Kenn Borek Ltd. We would like to express our sincere thanks to Alain Hubert and his team at the Belgian Princess Elisabeth station and the crews at Novo Runway for their logistic support.

Parts of this study was financially supported by Deutsche Forschungsgemeinschaft (DFG) within the frame of the Collaborative Research Programme SPP 1158 “(grants LA1080/9 to A. Läufer and LI $745 / 15$ to F. Lisker) in the framework of the priority programme 1158 "Antarctic Research with comparative investigations in Arctic ice areas."

Finally, we thank Sergei Pisarevsky and Toshiaki Tsunogae for the critical and helpful reviews.

\section{References}

Adachi, T., Osanai, Y., Hokada, T., Nakano, N., Baba, S., Toyoshima, T., 2013. Timing of metamorphism in the central Sør Rondane Mountains, eastern Dronning Maud Land, East Antarctica: constrains from SHRIMP zircon and EPMA monazite dating. Precambrian Research 234:136-160. https://doi.org/10.1016/j.precamres.2012.11.011.

Blakely, R.J., 1995. Potential Theory in Gravity and Magnetic Applications. Cambridge University Press.

Blakely, R.J., Simpson, R.W., 1986. Approximating edges of source bodies from magnetic or gravity anomalies. Geophysics 51 (7):1494-1498. https://doi.org/10.1190/ 1.1442197.

Boger, S.D., Wilson, C.J.L., Fanning, C.M., 2001. Early Paleozoic tectonism within the East Antarctic craton: The final suture between east and west Gondwana? Geology 29, 463-466.

Cordell, L., Grauch, V.J.S., 1982. Mapping basement magnetization zones from aeromagnetic data in the San Juan Basin, New Mexico. SEG Technical Program Expanded Abstracts:pp. 246-247 https://doi.org/10.1190/1.1826915.
Dalziel, I.W.D., 1991. Pacific margins of Laurentia and East Antarctica, Australia as a conjugate rift pair: Evidence and implications for an Eocambrian supercontinent. Geology 19, 598-601.

Eagles, G., König, M., 2018. A model of plate kinematics in Gondwana breakup Publikationsdatum. Geophysical Journal International 173 (2), 703-717.

Eagles, G., Karlsson, N., Ruppel, A., Steinhage, D., Jokat, W., Läufer, A., 2018. Erosion at extended continental margins: insights from new aerogeophysical data in eastern Dronning Maud Land. Gondwana Research (in review).

Elburg, M., Jacobs, J., Andersen, T., Clark, C., Läufer, A., Ruppel, A., Krohne, N., Damaske, D. 2015. Early Neoproterozoic metagabbro-tonalite-trondhjemite of Sør Rondane (East Antarctica): implications for supercontinent assembly. Precambrian Research 259 (0), 189-206.

Elburg, M., Andersen, T., Jacobs, J., Läufer, A., Ruppel, A., Krohne, N., Damaske, D., 2016 One hundred and fifty million years of Pan-African magmatism in the Sør Rondane Mountains (East Antarctica): implications for Gondwana assembly. The Journal of Geology 124 (1), 1-26.

Fitzsimons, I.C.W., 2000. A review of tectonic events in the East Antarctic Shield and their implications for Gondwana and earlier supercontinents. Journal of African Earth Sciences $31,3-23$.

Fitzsimons, I.C.W., 2003. Proterozoic basement provinces of southern and southwestern Australia, and their correlation with Antarctica. Geological Society, London, Special Publications 206, 93-130.

Fretwell, P., Pritchard, H.D., Vaughan, D.G., Bamber, J., Barrand, N., Bell, R., Bianchi, C., Bingham, R., Blankenship, D., Casassa, G., 2013. Bedmap2: improved ice bed, surface and thickness datasets for Antarctica. The Cryosphere 7 (1).

Fritz, H., Abdelsalam, M., Ali, K.A., Bingen, B., Collins, A.S., Fowler, A.R., Ghebreab, W. Hauzenberger, C.A., Johnson, P.R., Kusky, T.M., Macey, P., Muhongo, S., Stern, R.J., Viola, G., 2013. Orogen styles in the East African Orogen: A review of the Neoproterozoic to Cambrian tectonic evolution. Journal of African Earth Sciences 86:65-106. https://doi.org/10.1016/j.jafrearsci.2013.06.004, https://www. sciencedirect.com/science/article/pii/S1464343X13001040.

Golynsky, A., Blankenship, D., Chiapini, M., Damaske, D., Ferraccioli, S., Finn, C., Golynsky, D., Goncharov, A., Ishihara, T., Ivanov, S., Jokat, W., Kim, H.R., König, M., Masolov, V. Nogi, Y., Sand, M., Studinger, M., 2007. New magnetic anomaly map of East Antarctica and surrounding regions. In: Cooper, A., Raymond, C., Team, I.E. (Eds.) Antarctica: A Keystone in a Changing WorldOnline Proceedings for the Tenth International Symposium on Antarctic Earth Sciences Volume 2007-1047, U.S. Geological Survey Open-File Report.

Hiroi, Y., Shiraishi, K., Motoyoshi, Y., 1991. Late Proterozoic paired metamorphic complexes in East Antarctica, with special reference to the tectonic significance of ultramafic rocks. Geological Evolution of Antarctica, pp. 83-87.

Jacobs, J., Thomas, R.J., 2004. Himalayan-type indenter-escape tectonics model for the southern part of the late Neoproterozoic-early Paleozoic East African-Antarctic Orogen. Geology 32 (8), 721-724.

Jacobs, J., Fanning, C.M., Henjes-Kunst, F., Olesch, M., Paech, H.J., 1998. Continuation of the Mozambique Belt into East Antarctica: Grenville-age metamorphism and polyphase Pan-African high-grade events in central Dronning Maud Land. The Journal of Geology 106, 385-406.

Jacobs, J., Bauer, W., Fanning, C.M., 2003. Late Neoproterozoic/Early Palaeozoic events in central Dronning Maud Land and significance for the southern extension of the East African Orogen into East Antarctica. Precambrian Research 126 (1-2):27-53. https://doi.org/10.1016/S0301-9268(03)00125-6.

Jacobs, J., Pisarevsky, S., Thomas, R.J., Becker, T., 2008. The Kalahari Craton during the assembly and dispersal of Rodinia. Precambrian Research 160 (1-2):142-158. https:// doi.org/10.1016/j.precamres.2007.04.022.

Jacobs, J., Elburg, M., Läufer, A., Kleinhanns, I.C., Henjes-Kunst, F., Estrada, S., Ruppel, A.S. Damaske, D., Montero, P., Bea, F., 2015. Two distinct Late Mesoproterozoic/Early Neoproterozoic basement provinces in central/eastern Dronnning Maud Land, East Antarctica: the missing link, $15-21^{\circ}$ E. Precambrian Research 265:249-272. https:// doi.org/10.1016/j.precamres.2015.05.003.

Jacobs, J., Opås, B., Elburg, M.A., Läufer, A., Estrada, S., Ksienzyk, A.K., Damaske, D. Hofmann, M., 2017. Cryptic sub-ice geology revealed by a U-Pb zircon study of glacial till in Dronning Maud Land, East Antarctica. Precambrian Research 294 $1-14$.

Johnson, P.R., Woldehaimanot, B., 2003. Development of the Arabian-Nubian Shield: perspectives on accretion and deformation in the northern East African Orogen and the assembly of Gondwana. Geological Society, London, Special Publications 206 (1): 289-325. https://doi.org/10.1144/gsl.sp.2003.206.01.15.

Johnson, P.R., Andresen, A., Collins, A.S., Fowler, A.R., Fritz, H., Ghebreab, W., Kusky T., Stern, R.J., 2011. Late Cryogenian-Ediacaran history of the Arabian-Nubian Shield: A review of depositional, plutonic, structural, and tectonic events in the closing stages of the northern East African Orogen. Journal of African Earth Sciences 61 (3):167-232. https://doi.org/10.1016/j.jafrearsci.2011.07.003, https:// www.sciencedirect.com/science/article/pii/S1464343X11001269.

Kamei, A., Horie, K., Owada, M., Yuhara, M., Nakano, N., Osanai, Y., Adachi, T., Hara, Y Terao, M., Teuchi, S., Shimura, T., Tsukada, K., Hokada, T., Iwata, C., Shiraishi, K. Ishizuka, H., Takahashi, Y., 2013. Late Proterozoic juvenile arc metatonalite and adakitic intrusions in the Sør Rondane Mountains, eastern Dronning Maud Land, Antarctica. Precambrian Research 234, 47-62.

Kitano, I., Osanai, Y., Nakano, N., Adachi, T., 2016. Detrital zircon provenances for metamorphic rocks from southern Sør Rondane Mountains, East Antarctica: a new report of Archean to Mesoproterozoic zircons. Journal of Mineralogical and Petrological Sciences 111 (2):118-128. https://doi.org/10.2465/jmps.151001.

Kröner, A., 2001. The Mozambique belt of East Africa and Madagascar: significance of zircon and Nd model ages for Rodinia and Gondwana supercontinent formation and dispersal. South African Journal of Geology 104 (2), 151-166. 
Meert, J.G., 2003. A synopsis of events related to the assembly of eastern Gondwana. Tectonophysics 362, 1-40.

Mieth, M., Jokat, W., 2014. New aeromagnetic view of the geological fabric of southern Dronning Maud Land and Coats Land, East Antarctica. Gondwana Research 25 (1): 358-367. https://doi.org/10.1016/j.gr.2013.04.003.

Mieth, M., Jacobs, J., Ruppel, A., Damaske, D., Läufer, A., Jokat, W., 2014. New detailed aeromagnetic and geological data of eastern Dronning Maud Land: Implications for refining the tectonic and structural framework of Sør Rondane, East Antarctica. Precambrian Research 245:174-185. https://doi.org/10.1016/j.precamres.2014.02.009, https://www. sciencedirect.com/science/article/pii/S0301926814000527.

Miller, H.G., Singh, V., 1994. Potential field tilt - a new concept for location of potentia field sources. Journal of Applied Geophysics 32 (2):213-217. https://doi.org/ 10.1016/0926-9851(94)90022-1.

Motoyoshi, Y., Ishikawa, M., 1997. Metamorphic and structural evolution of granulites from Rundvågshetta, Lützow-Holm Bay, East Antarctica. Sienna, The Antarctic Region: Geological Evolution and Processes (65-72 pp.).

Moyes, A.B., Barton, J.M., Groenewald, P.B., 1993. Late Proterozoic to Early Palaeozoic tectonism in Dronning Maud Land, Antarctica: supercontinental fragmentation and amalgamation. Journal of the Geological Society 150, 833-842.

Muhongo, S., Lenoir, J.-L., 1994. Pan-African granulite-facies metamorphism in the Mozambique Belt of Tanzania: U-Pb zircon geochronology. Journal of the Geological Society 151 (2):343-347. https://doi.org/10.1144/gsjgs.151.2.0343.

Nogi, Y., Jokat, W., Kitada, K., Steinhage, D., 2013. Geological structures inferred from airborne geophysical surveys around Lützow-Holm Bay, East Antarctica. Precambrian Research 234 (0):279-287. https://doi.org/10.1016/j.precamres.2013.02.008.

Osanai, Y., Nogi, Y., Baba, S., Nakano, N., Adachi, T., Hokada, T., Toyoshima, T., Owada, M. Satish-Kumar, M., Kamei, A., Kitano, I., 2013. Geologic evolution of the Sør Rondane Mountains, East Antarctica: Collision tectonics proposed based on metamorphic processes and magnetic anomalies. Precambrian Research 234:8-29, https://www. sciencedirect.com/science/article/pii/S0301926813001836?via\%3Dihub.

Otsuji, N., Satish-Kumar, M., Kamei, A., Tsuchiya, N., Kawakami, T., Ishikawa, M. Grantham, G.H., 2013. Late-Tonian to early-Cryogenian apparent depositional ages for metacarbonate rocks from the Sør Rondane Mountains, East Antarctica. Precambrian Research 234:257-278. https://doi.org/10.1016/j.precamres.2012.10.016.

Owada, M., Kamei, A., Horie, K., Shimura, T., Yuhara, M., Tsukada, K., Osanai, Y., Baba, S., 2013. Magmatic history and evolution of continental lithosphere of the Sør Rondane Mountains, eastern Dronning Maud Land, East Antarctica. Precambrian Research 234 (0), 63-84

Riedel, S., Jacobs, J., Jokat, W., 2013. Interpretation of new regional aeromagnetic data over Dronning Maud Land (East Antarctica). Tectonophysics 585:161-171. https://doi.org/ 10.1016/j.tecto.2012.10.011.

Rignot, E., Mouginot, J., Scheuchl, B., 2011. Ice Flow of the Antarctic Ice Sheet. Science 333 (6048):1427-1430. https://doi.org/10.1126/science.1208336, http://science. sciencemag.org/content/333/6048/1427.

Roest, W.R., Verhoef, J., Pilkington, M., 1992. Magnetic interpretation using the 3-D analytic signal. Geophysics 57 (1):116-125. https://doi.org/10.1190/1.1443174.

Ruppel, A.S., Läufer, A., Jacobs, J., Elburg, M., Krohne, N., Damaske, D., Lisker, F., 2015. The Main Shear Zone in Sør Rondane, East Antarctica: Implications for the late-PanAfrican tectonic evolution of Dronning Maud Land. Tectonics 34 (6):1290-1305. https://doi.org/10.1002/2014TC003763.

Shackleton, R.M., 1996. The final collision zone between East and West Gondwana: where is it? Journal of African Earth Sciences 23 (3), 271-287.
Shiraishi, K., Asami, M., Ohta, Y., 1982. Plutonic and metamorphic rocks of Massif-A in the Yanato Mountains, East Antarctica. Memoirs of National Institute of Polar Research. vol. 21, pp. 21-31 (Special issue)

Shiraishi, K., Hiroi, Y., Ellis, D., Fanning, C., Motoyoshi, Y., Nakai, Y., 1992. The first report of a Cambrian orogenic belt in East Antarctica - an ion microprobe study of the LützowHolm Complex. Recent Progress in Antarctic Earth Science. Terra Scientific Publishing Company, Tokyo, pp. 29-35.

Shiraishi, K, Ellis, D. . Hiroi, Y, Fanning C.M., Motoyoshi, Y, Nakai, Y, 1994 Cambrian Orogenic Belt in East Antarctica and Sri Lanka: Implications for Gondwana Assembly. The Journal of Geology 102:47-65, https://www.journals.uchicago.edu/doi/abs/ 10.1086/629647.

Shiraishi, K., Hokada, T., Fanning, C., Misawa, K., Motoyoshi, Y., 2003. Timing of thermal events in eastern Dronning Maud Land, East Antarctica. Polar Geoscience 16, 76-99.

Shiraishi, K., Dunkley, D.J., Hokada, T., Fanning, C.M., Kagami, H., Hamamoto, T., 2008. Geochronological constraints on the Late Proterozoic to Cambrian crustal evolution of eastern Dronning Maud Land, East Antarctica: a synthesis of SHRIMP U-Pb age and Nd model age data. Geological Society, London, Special Publications 308 (1), 21-67.

Stern, R.J., 1994. Arc-assembly and continental collision in the Neoproterozoic African Orogen: implications for the consolidation of Gondwanaland. Annual Review of Earth and Planetary Sciences 22, 319-351.

Stern, R.J., 2002. Crustal evolution in the East African Orogen: a neodymium isotopic perspective. Journal of African Earth Sciences 34 (3-4):109-117. https://doi.org/ 10.1016/S0899-5362(02)00012-X.

Takahashi, K., Tsunogae, T., Santosh, M., Takamura, Y., Tsutsumi, Y., 2017. Paleoproterozoic (ca. $1.8 \mathrm{Ga}$ ) arc magmatism in the Lützow-Holm Complex, East Antarctica: implications for crustal growth and terrane assembly in erstwhile Gondwana fragments. Journal of Asian Earth Sciences https://doi.org/10.1016/j. jseaes.2017.07.053.

Tsunogae, T. Yang Q-Y., Santosh, M., 2015. Early Neoproterozoic arc magmatism in the Lützow-Holm Complex, East Antarctica: Petrology, geochemistry, zircon U-Pb geochronology and Lu-Hf isotopes and tectonic implications. Precambrian Research 266 (Supplement C):467-489. https://doi.org/10.1016/j.precamres.2015.05.040, https://www.sciencedirect.com/science/article/pii/S0301926815001898.

Tsunogae, T., Yang, Q.-Y., Santosh, M., 2016. Neoarchean-Early Paleoproterozoic and Early Neoproterozoic arc magmatism in the Lützow-Holm Complex, East Antarctica: Insights from petrology, geochemistry, zircon $\mathrm{U}-\mathrm{Pb}$ geochronology and $\mathrm{Lu}-\mathrm{Hf}$ isotopes. Lithos 263 (Supplement C):239-256. https://doi.org/10.1016/j.lithos.2016.02.010, https://www.sciencedirect.com/science/article/pii/S0024493716000827.

Van Autenboer, T., Loy, V., 1972. Recent geological investigations in the Sor Rondane mountains, Belgicafjella and Sverdrupfjella, Dronning Maud Land, Antarctica. Prooeedings SCAR-IUGS Symposium on Antarctic Geology, Universitetsforlaget, Oslo (563-571 pp.).

Verduzco, B., Fairhead, J.D., Green, C.M., MacKenzie, C., 2004. New insights into magnetic derivatives for structural mapping. The Leading Edge 23 (2):116-119. https://doi.org/ 10.1190/1.1651454

Zhao, J.X., Shiraishi, K., Ellis, D.J., Sheraton, J.W., 1995. Geochemical and isotopic studies of syenites from the Yamato Mountains, East Antarctica: Implications for the origin of syenitic magmas. Geochimica et Cosmochimica Acta 59 (7):1363-1382. https://doi. org/10.1016/0016-7037(95)00050-A, https://www.sciencedirect.com/science/article/pii/001670379500050A. 